\title{
The Paradigm of Huntington's Disease: Therapeutic Opportunities in Neurodegeneration
}

\author{
Julie Leegwater-Kim and Jang-Ho J. Cha* \\ Department of Neurology, Massachusetts General Hospital, Charlestown, Massachusetts 02129-4404
}

Summary: Despite a relatively small number of affected patients, Huntington's disease (HD) has been a historically important disease, embodying many of the major themes in modern neuroscience, including molecular genetics, selective neuronal vulnerability, excitotoxicity, mitochondrial dysfunction, apoptosis, and transcriptional dysregulation. The discovery of the $H D$ gene in 1993 opened the door to the mechanisms of HD pathogenesis.
Multiple pathologic mechanisms have been discovered, each one serving as a potential therapeutic target. HD thus continues to serve as a paradigmatic disorder, with basic bench research generating clinically relevant insights and stimulating the development of therapeutic human trials. Key Words: Huntington's disease, apoptosis, excitotoxicity, mitochondria, transcription, transplantation.

\section{INTRODUCTION}

In many ways, Huntington's disease (HD) has been a model disorder. HD was the first autosomal dominant disorder in which the then-novel technique of "reverse genetics" was successfully applied. ${ }^{1-4}$ It would be another 10 years until the gene was found. Excitotoxicity, the idea that overexcitation could lead to the death of neurons, was first seriously considered in the context of HD. ${ }^{5-8}$ Excitotoxicity has now been implicated in a host of neurologic disorders. ${ }^{9-11}$ Similarly, many of the major ideas in modern neuroscience, including mitochondrial dysfunction, apoptosis, and transcriptional dysregulation, were initially derived from the HD field or have been explored substantially in HD. When the $H D$ gene was eventually identified as a CAG trinucleotide repeat disorder, HD joined a novel class of neurodegenerative diseases, the polyglutamine disorders. ${ }^{12,13}$ The discovery of intracellular aggregates of mutant huntingtin bolstered the emerging concept that all neurodegenerative disorders are diseases of protein misfolding. ${ }^{14-17}$

Clinically, HD has also been a paradigmatic disease. As for so many neurologic diseases, there is no effective therapy for $\mathrm{HD}$, which remains a progressive, fatal dis-

*Address correspondence and reprint requests to Jang-Ho J. Cha, M.D., Ph.D., MassGeneral Institute for Neurodegenerative Disease, Department of Neurology, Massachusetts General Hospital/B114-2000, 114 16th Street, Charlestown, MA 02129-4404. E-mail: cha@helix.mgh. harvard.edu. order. However, just as advances in molecular genetics made possible predictive genetic testing for HD, recent laboratory discoveries are pointing the way to novel therapeutic approaches. ${ }^{18}$ Large multi-center clinical HD trials have been completed, and many more trials are planned. In this review, we outline recent advances in understanding the molecular pathogenesis of $\mathrm{HD}$, as well as the therapeutic opportunities created by such advances.

\section{OVERVIEW OF HUNTINGTON'S DISEASE}

\section{Clinical features}

HD is a neurodegenerative disease characterized by the clinical triad of movement disorder, dementia and psychiatric disturbance. ${ }^{19}$ With an incidence of 4 to 10 per 100,000, HD afflicts 30,000 people in the United States. Another 250,000 persons are genetically at risk. HD is inherited in an autosomal dominant manner and typically develops in the fourth or fifth decade of life. Initially, patients demonstrate personality changes and develop small involuntary movements. As the disease progresses, the movement disorder becomes more pronounced, and cognitive deficits as well as psychiatric disturbances occur. Though the movement disorder is typically chorea, virtually any type of movement disorder is seen, including dystonia, rigidity, myoclonus, and athetosis. Cognitive dysfunction can be due to striatal or cortical degeneration and includes dementia and difficulties with executive functioning. Psychiatric disturbances 
most commonly manifest as apathy and depression but obsessive-compulsive disorder, psychosis, paranoia, and substance abuse also occur. ${ }^{20}$

Disease duration is 10 to 30 years, and later symptoms include rigidity, dystonia, and bradykinesia. Weight loss is a common feature of the disease. Death usually results from aspiration pneumonia secondary to dysphagia, or from complications resulting from falls or chronic illness; suicide is another cause of death. Currently, there is no effective treatment to delay the onset or slow the progression of HD.

A juvenile form of HD exists and is most often inherited through paternal transmission. The movement disorder tends to be more parkinsonian than the adult form and is characterized by bradykinesia, rigidity, and resting tremor. Seizures are also common. Patients with juvenile onset of the disease have a more severe course of disease with an average duration of 5 to 20 years.

\section{Pathology}

Pathologically, HD is characterized by the selective loss of efferent medium spiny neurons in the striatum (caudate nucleus and putamen) of the basal ganglia. ${ }^{21}$ The striatum is comprised of numerous neuronal subtypes which include medium spiny projection neurons and interneurons. The latter category encompasses the medium aspiny reduced nicotinamide adenine dinucleotide phosphate (NADPH)-diaphorase-positive, neuronal nitric oxide synthase (nNOS)-positive neurons and large aspiny cholinergic neurons. Unlike the medium spiny projection neurons, interneuron populations are relatively spared in HD. ${ }^{22-26}$ The factors that render striatal projection neurons more susceptible to damage are unknown.

Although the striatum is the most profoundly affected region in $\mathrm{HD}$, degenerative changes in the cortex, thalamus, and subthalamic nucleus have also been reported in HD. ${ }^{27,28}$ Therefore, the changes in the striatum reflect a relative selective vulnerability to cell death. One possible explanation is that other brain regions in HD are affected, but at a slower rate than the striatum. In juvenile $\mathrm{HD}$, in which the rate of disease progression is much faster, cortical pathology is more significant.

The pathologic changes in HD appear to precede the frank appearance of disease symptoms. Decreases in mRNA encoding dopamine D1 and D2 receptors have been found in the striatum of patients in the early stages of HD. ${ }^{29}$ Positron emission tomography studies of genepositive but clinically asymptomatic patients demonstrate that dopamine D1 and D2 receptors are decreased before the onset of symptoms. ${ }^{30-32}$ In transgenic mouse models of HD, the alterations in brain receptor expression precede the development of obvious neurological symptoms. ${ }^{33-35}$ Thus, neuronal dysfunction predates the appearance of neurologic symptomatology in HD.

\section{HD is a polyglutamine disorder}

Although a chromosomal marker was identified in $1983,{ }^{3}$ it was not until 1993 that the HD gene was discovered. $^{36}$ The IT15 ("interesting transcript 15") gene encodes a $348-\mathrm{kDa}$ protein called huntingtin whose amino acid sequence does not resemble that of any known protein. The $5^{\prime}$ end of the gene contains a polymorphic trinucleotide repeat (cytosine-adenineguanosine, CAG) which encodes a series of glutamines. Normal persons have CAG repeat lengths of 7-34. The CAG repeat is expanded and unstable in HD patients, with repeat length inversely correlating with age of disease onset. Repeat lengths of $>40$ glutamines invariably produce HD, and repeats of $>100$ glutamines invariably cause juvenile onset. ${ }^{37} \mathrm{CAG}$ repeat lengths of 35-39 are considered intermediate alleles. ${ }^{38}$

By virtue of having an expanded polyglutamine moiety, HD becomes a member of a novel class of neurodegenerative disorders known as CAG trinucleotide repeat disorders or polyglutamine disorders..$^{12,39,40}$ Although some trinucleotide disorders such as myotonic dystrophy or fragile X mental retardation have expansions of repeats in noncoding regions of the gene, the CAG repeat disorders are distinct. In these disorders, the expansion of the CAG repeat (the codon encoding the amino acid glutamine) occurs within the coding region of the gene, and the disease gene is translated into protein. The polyglutamine disorders include spinobulbar muscular atrophy (SBMA or Kennedy's disease), dentatorubropallidoluysian atrophy (DRPLA), and several of the spinocerebellar ataxias (SCA-1, -2, -3, -6, -7, -12, and -17). Although these are relatively rare disorders, they share some remarkable features. All are autosomal dominant or sex-linked dominant diseases, usually with adult onset, characterized by progressive neurodegeneration of selected neuronal populations. For all polyglutamine disorders, higher numbers of repeats in the mutant gene correlates with an earlier age of onset. Polyglutamine protein-containing inclusions are another striking common feature, which are detected in human pathologic specimens as well as in transgenic mouse models. Interestingly, although all of the mutant proteins share the polyglutamine region, the other portions of the host proteins are not homologous. Given the remarkable similarities between these disorders, these observations point to the polyglutamine moiety as the most relevant portion of the molecular contributing to disease pathogenesis. ${ }^{41}$

Two experiments involving transgenic mice confirm the primary importance of the polyglutamine tract in disease pathogenesis. Bates and colleagues ${ }^{42}$ created lines of mice with a transgene containing only exon 1 of the human $H D$ gene. While exon 1 contains the polymorphic CAG region, there are 67 exons in total, and thus exon 1 comprises only about $3 \%$ of the complete gene. Remarkably, transgenic mice expressing a mutated 
exon 1 develop an abnormal neurologic phenotype that is reminiscent of HD: normal initial development, but later onset of motor and cognitive difficulties, weight loss, and early death. ${ }^{42}$ In another experiment, Ordway and colleagues $^{43}$ inserted CAG repeats into the mouse HPRT gene, which normally does not contain CAG repeats. Transgenic mice expressing these "ectopic" repeats developed an abnormal motor phenotype and ubiquitinated intranuclear inclusions, features which have been observed in a numbers of transgenic mouse models of polyglutamine diseases. While these observations certainly do not exclude a role for the remainder of the huntingtin molecule, they highlight the primary pathologic relevance of the expanded polyglutamine portion of the protein.

\section{Function of huntingtin}

Huntingtin itself has no clear homology to known proteins, and its normal function is not known. Huntingtin is certainly required for normal development, as knockout mice lacking their endogenous huntingtin die at embryonic stage. ${ }^{44,45}$ Mutant forms of huntingtin can rescue the embryonic lethality of the knockout mouse, indicating that the polyglutamine expansion does not remove all of the normal function of huntingtin. ${ }^{46}$ This observation also bolsters the idea that $\mathrm{HD}$ is a gain of function disease. Huntingtin is also required for normal hematopoiesis and spermatogenesis. ${ }^{46,47}$

Recent data support an anti-apoptotic role for normal (wild-type) huntingtin. ${ }^{48,49}$ Cattaneo and colleagues ${ }^{50}$ have found that wild-type huntingtin exerts its anti-apoptotic effects by preventing the processing of caspase- 9 . Wild-type huntingtin also promotes transcription of brain-derived neurotrophic factor (BDNF). ${ }^{51}$ Since wildtype huntingtin is itself cleaved in HD tissues, ${ }^{51,52}$ some of the features of HD may be the result of loss of function of wild-type huntingtin. Caspases have been implicated in the cleavage of both mutant and wild-type huntingtin. ${ }^{53,54}$ Wild-type huntingtin can also be cleaved by calpain, ${ }^{55,56}$ and an aspartyl protease. ${ }^{57}$ While proteolytic cleavage of wild-type huntingtin could lead to a loss of normal function, cleavage into smaller fragments also alters the nuclear trafficking of huntingtin. ${ }^{58-61}$ While huntingtin is predominantly cytoplasmic, a small fraction of full-length huntingtin is also normally found in the nucleus. ${ }^{62,63}$

\section{THEORIES OF PATHOGENESIS}

The exact mechanism by which neurons die in HD remains unknown. The discovery of the $H D$ gene, and, more recently, the development of transgenic mouse, fly, and worm models has led to an explosion of discovery of the pathogenic mechanisms caused by mutant huntingtin. Far from arriving at a unifying mechanism, there is in- stead robust evidence that multiple pathologic mechanisms occur in HD.

\section{Excitotoxicity}

The death of neurons as a result of overactivity of glutamate neurotransmission, a process termed excitotoxicity, has been an influential theme in modern neuroscience. Much of the support for the excitotoxic hypothesis has come from the HD field. ${ }^{64}$ The theory of excitotoxicity as a pathogenic mechanism in HD has emerged over the last few decades, beginning with the observation that injections of excitatory amino acids into the striatum of rodents and primates led to neuronal depletion and a neurologic phenotype that was similar to HD. As the striatum receives large glutamatergic input from corticostriatal afferents, it is a structure at risk of glutamate-mediated excitotoxic injury. Intrastriatal injections of glutamate agonists, particularly those acting at NMDA receptors, have been used to create animal models of HD. Of the NMDA agonists, quinolinic acid, an endogenous metabolite of tryptophan, has been shown to most closely mimic the neuropathology and neurologic phenotype of HD, producing selective degeneration of medium spiny neurons with sparing of interneuron populations. In addition, glutamate receptors have been shown to be reduced in human HD brains. ${ }^{67-69}$ In more recent studies, subsets of glutamate receptors, specifically the metabotropic glutamate receptor mGluR2, appear to be significantly decreased in a transgenic mouse model of HD. ${ }^{34}$ mGluR2 receptors down-regulate glutamate release at corticostriatal presynaptic terminals, and depletion of these receptors could lead to overstimulation of postsynaptic striatal neurons. Further data supporting the excitotoxic model show that there is increased sensitivity to NMDA receptor activation and enhanced excitotoxicity in HD transgenic mice. ${ }^{70-73}$ Finally, perturbations in glutamate handling in the brain may also contribute to excitotoxicity in HD as there appears to be down-regulation of the GLT-1 glial glutamate transporter in a transgenic mouse model of HD. ${ }^{74}$

In addition, mutant huntingtin may alter the structure of the postsynaptic apparatus. Recent data demonstrate an association in human cortex between huntingtin and PSD-95 (post-synaptic density protein 95, a protein that is involved in the post-synaptic clustering of NMDA receptors) that is mediated by the $\mathrm{SH} 3$ domain of PSD95. The presence of the polyglutamine expansion in mutant huntingtin appears to significantly reduce binding to PSD-95 and promotes sensitization of NMDA receptors. These data raise the intriguing possibility that wild-type huntingtin may function to modulate NMDA receptor activity by dissociating NMDA receptor-linked macromolecular complexes. ${ }^{75}$

Although the excitotoxic hypothesis is a persuasive one, there are still some features of HD that remain 
unexplained. For example, in addition to the striatum, the hippocampus, cortex, and cerebellum contain similar or higher levels of glutamate receptors, yet there is a strikingly selective loss of striatal neurons in HD. Thus, the high-level glutamate receptors cannot explain the regional specificity of HD pathology. One possibility is that the selective loss of striatal neurons is due to differences in glutamate receptor subtypes in these brain regions. The cell selectivity within the striatum remains similarly unexplained. Recent data suggest that regional expression of the NR2B receptor subunit of the NMDA receptor accounts for the severity of neuronal death in HD. ${ }^{76,77}$ Mutant huntingtin also selectively increases current flow through NMDA receptors comprised of NR1/NR2B subunits. ${ }^{72,73,78}$

\section{Apoptosis/caspases}

One of the major ideas in modern neuroscience is that neurons may die by inappropriately activating the apoptosis cell death program. ${ }^{79}$ Within the last decade, the role of apoptosis and caspases, the apoptosis-related cysteine proteases, has been proposed in the pathogenesis of HD. ${ }^{52,80,81}$ Apoptosis, also known as programmed cell death, is a feature of a number of chronic neurodegenerative diseases [Alzheimer's disease, amyotrophic lateral sclerosis (ALS), HIV dementia], and caspases are important in initiating and executing the cell death program. Recent data have shown that there is increased activation of caspase- 1 in pre-symptomatic and early symptomatic HD transgenic mice. ${ }^{52}$ In cellular model systems, expression of mutant huntingtin can induce apoptosis. $^{61,82,83}$ The normal and mutant huntingtin proteins are substrates for caspase- 1 and caspase- 3 , and both are cleaved, generating N-terminal fragments. ${ }^{53,84,85}$ The mutant huntingtin N-terminal fragments, which contain the expanded polyglutamine moeity, are translocated to the nucleus, where they accumulate into aggregates. The presence of these mutant $\mathrm{N}$-terminal fragments in the nucleus is a stimulus for caspase- 1 up-regulation. ${ }^{83}$ As the disease progresses, caspase- $3,-8$, and -9 are activated, and there is release of cytochrome $c$, which serves as an apoptotic trigger. ${ }^{86}$ Inhibition of caspase- 1 appears to slow disease progression in HD transgenic mice; transgenic HD mice also expressing a dominant-negative caspase-1 gene survived longer and had delayed appearance of symptoms, neuronal inclusions, and neurotransmitter receptor changes. ${ }^{52}$ The activation of caspases has also been shown in human HD striatal tissue. ${ }^{52,86,87}$

\section{Mitochondrial dysfunction}

Neurons are metabolically active cells; processes that affect mitochondrial function have disproportionate effects on neurons. Mitochondrial dysfunction has been proposed to underlie a number of neurodenegerative disorders, including HD. ${ }^{88-91}$ Defects in energy metabolism have been well-documented in the disorder: glucose me- tabolism is decreased in the brains of HD patients, ${ }^{92}$ lactate levels are increased in areas of HD brain, ${ }^{93}$ and the cerebrospinal fluid lactate/pyruvate ratio in HD patients is increased as compared with age-matched controls. ${ }^{94}$ In addition, metabolic defects in skeletal muscle have been reported, ${ }^{94,95}$ a finding consistent with observations that HD patients suffer progressive weight loss despite increased caloric intake. Thus, defects in energy metabolism appear to be widespread in HD, affecting both the brain and peripheral tissues.

Reports of changes in activity of enzymes involved in oxidative phosphorylation lend further support to the mitochondrial dysfunction hypothesis in HD. Reduced activity of the complex II enzyme succinate dehydrogenase $(\mathrm{SDH})$ has been found in postmortem HD brain tissue. ${ }^{96}$ In addition, a decrease in complex II-III activity in HD basal ganglia has been observed. ${ }^{97,98}$ Systemic administration of the mitochondrial toxin 3-nitropropionic acid (3-NP), an irreversible inhibitor of SDH, to nonhuman primates produces a movement disorder and cognitive deficits similar to HD. Histologic examination of the striatum 3-NP-treated animals reveals a pattern of neuronal loss similar to HD with abnormalities in medium spiny neurons and sparing of the NADPH diaphorase interneurons and nucleus accumbens. ${ }^{99,100}$ Malonate, another complex II inhibitor, has also been used to produce such "chemical lesion" models of HD. ${ }^{101}$

The mechanism by which mitochondrial dysfunction ultimately leads to neuronal death has been proposed to be linked to excitotoxicity because NMDA receptor antagonists can block the effect of mitochondrial inhibitors. ${ }^{102}$ Recent data show that 3-NP treatment induces long-term NMDA-mediated excitation in medium spiny neurons. ${ }^{103}$ These observations lend credence to the "weak excitotoxic hypothesis" in which mitochondrial inhibition functions to tip the excitotoxic balance toward neurotoxicity. ${ }^{104}$

Recently, Panov and colleagues ${ }^{105}$ have demonstrated that mitochondria isolated from HD patient lymphoblasts have reduced calcium buffering capacity. In addition to being able to take up less ionized calcium than wild-type mitochondria, HD mitochondria are relatively depolarized. Since the mitochondrial membrane potential is directly related to ATP production, reduced membrane potential likely contributes to energetic failure in this disease. Interestingly, in an HD knock-in mouse model, there is a progressive reduction in the amount of cyclic AMP, indicating an energy deficit. ${ }^{106}$

While derangements in energy metabolism are welldocumented in HD, it is still unclear whether these defects are a cause of the disease or a consequence. Some studies have shown that disorders in metabolism are found in both presymptomatic and symptomatic HD individuals (glucose, lactate, and muscle). However, other studies have shown no evidence of perturbations in mi- 
tochondrial transport in the brains of postmortem HD patients and in transgenic mice expressing full-length mutant huntingtin. ${ }^{107}$ Therefore the exact role of mitochondrial dysfunction in the pathogenesis of HD has yet to be determined.

\section{Transcriptional dysregulation}

The identification of the $H D$ gene has led to new theories regarding pathogenesis. As detailed above, huntingtin contains a polyglutamine stretch, the expansion of which confers a gain-of-function property. Polyglutamine tracts are a feature of transcription factor proteins (e.g., Sp1, TBP, TRAM1, and CBP) and can act as activation domains for transcription factors in vitro. Mutant huntingtin has been shown to have an aberrant nuclear localization as well as altered protein-protein interactions, and the combination of these observations suggests mutant huntingtin might act to sequester polyglutamine-containing nuclear transcription factors, thereby leading to transcriptional dysregulation and subsequent neuronal death. ${ }^{108}$ Recent data have shown reduced expression of a number of genes in a transgenic mouse model of $\mathrm{HD}^{33,34,109,110}$ suggesting that transcriptional repression is the main result of dysregulation. In addition, a number of studies have demonstrated that huntingtin is able to bind transcription factors resulting in decreased activity of these proteins. ${ }^{111-113}$ Not surprisingly, many of the transcription factors with altered activity in HD directly or indirectly regulate histone acetylation, a process which helps regulate transcription through covalent modification of chromatin.

\section{NEUROTHERAPEUTICS IN HD}

Currently there is no cure for HD, and there are no therapies which significantly slow the progression of the disease or delay its onset. However, basic science research into the pathogenesis of HD has led to a number of different and promising areas of neurotherapeutics. One significant advantage in the study of HD is the proliferation of animal and invertebrate disease models which have aided not only in investigating the function of huntingtin, but also in screening and testing potential therapeutic drugs.

\section{Excitotoxicity}

The excitotoxic hypothesis is a well-studied mechanism in HD pathology and has led to the identification of possible neuroprotective compounds. As detailed above, injection of quinolinic acid into the striatum of rodents recapitulates many of the features of HD and has therefore been used as a model to identify and test potential neuroprotective agents. N-acetyl-aspartyl-glutamate, a compound which has antagonist (and agonist) activity at NMDA receptors and agonist activity at the mGluR3 metabotropic glutamate receptor, has been found to re- duce lesion volume in quinolinic-acid-treated rats. ${ }^{117}$ (S)-4-Carboxy-3-hydroxyphenylglycine, which acts at metabotropic glutamate receptors, has also been shown to protect against excitotoxicity in rats that have received intrastriatal injection of quinolinic acid. ${ }^{118}$

Riluzole, an inhibitor of glutamate release that is used for ALS, was found to be protective against quinolinate lesions. ${ }^{119}$ An open-label human trial found that riluzole reduced chorea and showed decreased levels of cerebral lactate, as assessed by magnetic resonance spectroscopy. ${ }^{120}$ Another open-label trial of riluzole also demonstrated transient motor improvement in human HD subjects. ${ }^{121}$ Riluzole has also been studied in a transgenic mouse model of HD. ${ }^{122}$ Mice who received riluzole had increased lifetime with delay in weight loss. Neuropathologically, the striata of riluzole-treated mice revealed fewer and smaller nuclear aggregates than the striata of untreated transgenic mice. Interestingly, riluzole has also been found to up-regulate the levels of several key neurotrophic factors, including BDNF and glial-derived neurotrophic factor (GDNF). ${ }^{123}$ A large multi-center placebo-controlled human clinical trial of riluzole is currently underway in Europe.

The recent finding that specific NMDA receptor subtypes (those comprised of NR1A/NR2B subunits) are partly responsible for the selective striatal neuronal vulnerability in HD suggests that subunit-specific antagonists may have a therapeutic role in HD. Ifenprodil, an NR2B-specific antagonist, has been shown to eliminate excitotoxic cell death in medium spiny neurons from transgenic and wild-type mice after exposure to NMDA. ${ }^{73}$

A recent multi-center trial called (CARE-HD) (Coenzyme Q10 and Remacemide in Huntington's Disease) tested the effects of coenzyme Q10, an antioxidant and cofactor involved in mitochondrial electron transfer, and remacemide, a noncompetitive NMDA receptor antagonist. ${ }^{124}$ In the largest randomized, placebo-controlled clinical HD trial to date, 348 patients were treated for 24 months with either coenzyme Q10, remacemide, a combination of both drugs, or none. In two different lines of transgenic mice, the combination of these two compounds demonstrated benefit. ${ }^{125,126}$ However, in the CARE-HD trial, there was no evidence of any benefit of remacemide, either alone or in combination with coenzyme Q10.

In addition to glutamate receptor subtypes, other receptor subtypes have been implicated in the pathogenesis of HD. Defects in the locus coeruleus-noradrenergic system have been observed in HD and the blockade of the presynaptic inhibitory $\alpha 2$-adrenergic receptors has been studied in the quinolinate lesion model. Administration of efaroxan and idazoxan, two $\alpha 2$-adrenergic receptor antagonists, to quinolinate-injected mice was found to decrease certain behavioral and biochemical characteris- 
tics of HD, specifically ipsiversive circling responses to apomorphine and choline acetyltransferase deficit in the affected striatum. ${ }^{127}$

Dopamine has been postulated to be involved in neurotoxicity seen in HD. ${ }^{128}$ Transgenic HD mice have reduced levels of dopamine ${ }^{129}$; numerous studies have found decreased dopamine receptors in both human and transgenic mouse models of HD. ${ }^{130}$ Transgenic HD mice given L-dopa experience transient improvement in motor symptoms, but later show signs of increased toxicity. ${ }^{131}$

\section{Mitochondrial toxicity}

Molecules that function to increase energy by boosting ATP stores have been studied for their potential neuroprotective effects. Both creatine and cyclocreatine have been investigated in animal models of HD. In rats treated with 3-NP, oral creatine supplementation produced significant protection against malonate- and 3-NP-induced lesions. ${ }^{132}$ Cyclocreatine protected against malonate-induced but not 3-NP lesions. The neuroprotective effects of creatine have also been demonstrated in a transgenic HD mice. ${ }^{133}$ Transgenic R6/2 mice given oral supplementation with creatine exhibited improved survival, delayed atrophy of striatal neurons and delayed formation of huntingtin-positive aggregates. In addition, body weight was significantly greater in creatine-treated transgenic mice and motoric ability, as measured by performance of the Rotarod test, was significantly improved in those animals. These data support a role for metabolic dysfunction as a pathogenic component of HD and suggest a potential role for ATP repletion via creatine supplementation as a therapeutic strategy. Human clinical trials of creatine in HD patients are underway.

Other studies have investigated the therapeutic potential of antioxidants. Both vitamin $\mathrm{E}$ and idebenone have been tested in clinical trials and found to have no significant impact on functional decline in HD. ${ }^{134,135}$ OPC14117, a lipophilic free-radical scavenger that concentrates in the brain has been tested in a safety and tolerability trial. ${ }^{136}$ The CARE-HD trial tested the effects of coenzyme Q10, an antioxidant and cofactor involved in mitochondrial electron transfer, as well as remacemide. ${ }^{124}$ Patients were randomized to receive one, none, or both treatments. Neither intervention showed significant change in total functional capacity (TFC), although patients treated with coenzyme Q10 showed a trend toward slowing in TFC decline (13\%) over 30 months. In addition, there were beneficial trends on certain cognitive tests and tests of behavior in the coenzyme Q10-treated group. Interestingly, when both compounds were tested in two transgenic mouse models of HD, each compound was found to extend survival time and delay onset of motor deficits, cerebral atrophy, weight loss, and intranuclear inclusions. ${ }^{125,126}$ When the compounds were administered together they were found to have additive beneficial effects. The discrepancy between mouse and human trial results highlights the difficulty in animal models of HD in predicting efficacy in humans. The CARE-HD trial was powered to detect a difference of $40 \%$ slowing; thus a $13 \%$ slowing is not large enough to be considered statistically significant.

\section{Apoptosis/caspases}

Although there is scant evidence for apoptosis in human HD, the demonstration that inhibiting caspase-1 could extend lifespan in transgenic HD mice gave credence to the idea that apoptosis was a legitimate target for therapeutics. ${ }^{52}$ Minocycline, a second-generation tetracycline, has been shown to inhibit caspase-1 and inducible NOS after experimental ischemia and to reduce infarct size. ${ }^{137,138}$ Minocycline was recently tested in transgenic HD mice and found to delay motoric decline (as measured by Rotarod performance) and extend survival time by $14 \%$. Minocycline, however, did not affect weight, nor did it inhibit the formation of intranuclear inclusions or decrease in receptor binding. In addition, it was found that inhibition of both caspase-1 and caspase- 3 was required for neuroprotection as drugs targeting one or the other did not extend survival. ${ }^{139}$ As minocycline has been used in humans and known to have few side effects, it is a promising candidate for $\mathrm{HD}$ clinical trials. A phase II clinical trial assessing the safety and efficacy of minocycline in human HD patients has recently been completed. While minocycline is unlikely to be a cure for HD, in some ways it is the ideal first treatment; it is an inexpensive drug and has few side effects, and there are millions of patient-years of tolerability and toxicity experience. Minocycline may someday be one of the drugs that is used in a combinatorial "cocktail" approach, such as is currently used for HIV/ Acquired Immune Deficiency Syndrome.

Cystamine, a caspase inhibitor, has also been studied in transgenic HD mice. Cystamine was originally tested as a therapeutic candidate given its ability to inhibit transglutaminases. Transglutaminases have been implicated as a possible mechanism of aggregate formation, by possibly cross-linking molecules of mutant huntingtin. Because mutant huntingtin aggregation appeared to correlate with disease phenotype, a transglutaminase inhibitor such as cystamine was tested for its potential ability to reduce aggregate formation and, in turn, extend survival. Both oral and intraperitoneal administration of cystamine extended survival in transgenic HD mice and reduced the number and size of aggregates ${ }^{140} \cdot{ }^{141} \mathrm{Re}$ cently, cystamine has been found to inhibit caspase-3 activity in vitro, suggesting that cystamine may work through a variety of mechanisms, including caspase inhibition, to prolong neuronal survival in HD. ${ }^{142}$ 


\section{Transcriptional dysregulation}

The role of transcriptional dysregulation in HD has been an exciting area of research over the last few years. ${ }^{108}$ Recent studies indicate that transcriptional repression is the main result of transcriptional dysregulation and could be explained by the recruitment and sequestering of transcription factors by mutant huntingtin. Because many of these nuclear factors are involved, directly or indirectly, in histone acetylation, neurotherapeutic research in this area has focused on histone deacetylase inhibitors (HDACs). The competing activities of histone acetyl transferases and histone deacetylases work to modify chromatin and thereby regulate transcription. Recent studies in cell culture, yeast, and Drosophila models of polyglutamine disease have shown that HDACs can reduce polyglutamine toxicity. ${ }^{143-145} \mathrm{~A}$ recent study tested the effects of suberoylanilide hydroxamic acid (SAHA) in a transgenic mouse model of HD. ${ }^{146}$ Mice treated with SAHA demonstrated improved motor impairment and less striatal neuronal loss though there was no significant effect on weight or polyglutamine aggregation. The testing of other HDAC inhibitors in mouse models of HD is underway.

\section{Restorative therapies}

One obvious approach to alleviating the damage caused by dead striatal neurons is to transplant a new source of neurons. Various approaches, including porcine xenografts ${ }^{147}$ and human fetal neurons ${ }^{148,149}$ have been tried. While there has not been definitive demonstration of clinical improvement with transplantation, a multi-center European trial is ongoing. ${ }^{148}$ In one trial, an HD patient who had received a fetal cell transplant died of presumably unrelated causes 18 months later. Autopsy analysis demonstrated that the implanted cells had survived, expressed appropriate neurochemical markers, and received innervation by host dopaminergic cells, demonstrating that transplanted tissue could persist for 18 months. ${ }^{150}$ As transplantation technology is improved, more advances will certainly be made. However, significant problems remain, not the least of which is that $\mathrm{HD}$ is a disease which affects multiple brain regions aside from the striatum. ${ }^{151}$

Various growth factors have been investigated in terms of their ability to maintain target cell populations. Activin-A, a nerve cell survival molecule, has also been tested in the quinolinic acid lesion model of HD. ${ }^{152}$ Quinolinate-treated rats that received intrastriatal infusion of activin-A displayed an improved phenotype with attenuation of cell death in a number of striatal nerve populations: striatal cholinergic interneurons and striatal projection neurons. Another approach has been to use genetically engineered cells that secrete various growth factors including ciliary neurotrophic factor, basic fibroblast growth factor, nerve growth factor, BDNF, NT3 and NT4. ${ }^{153-155}$ Interestingly, neurturin, a member of the GDNF growth factor family, demonstrated selective protection of enkephalin-containing striatal projections neurons, while GDNF selectively protected substance Pcontaining neurons in an excitotoxic lesion model of HD. ${ }^{155}$

One potential drawback of the transplantation literature is that these experiments have largely relied on chemical lesion models of HD. To date, there has been no report of restoring growth factors to a transgenic mouse model of HD, although deficits in BDNF have been reported..$^{51}$ There is one report or transplantation of anterior cingulate cortex into transgenic HD mice showing some motor improvement, pointing out the cortex as a possible target for transplantation. ${ }^{156}$

Stem cells have garnered substantial interest as a potential source of restorative neurons. ${ }^{157}$ A recent report points to an unsuspected source of neural stem cells: the Huntington's disease brain itself. Curtis et al. ${ }^{158}$ found an increase in cell proliferation in the subependymal layer adjacent to the caudate nucleus of the human HD brain. Interestingly, these proliferative cells expressed both neuronal and glial cell markers. Furthermore, the degree of cell proliferation increased with pathological severity and with increasing CAG repeats in the $H D$ gene. These observations raise the possibility that the HD brain itself could be coaxed into generating replacement neurons, especially if the rate of disease pathogenesis could be slowed by other means.

\section{SUMMARY}

Huntington's disease remains an important model disorder. The revolution in molecular genetics which led to discovery of the $H D$ gene in 1993 has opened the door to discovery of basic pathogenic mechanisms. While the elucidation of multiple pathogenic mechanisms may be confusing, the other benefit is that such understanding permits development of multiple therapeutic targets. Looking forward, Huntington's disease is likely to remain an important model disease in neurotherapeutics.

Examination of human postmortem material as well as informative transgenic animal models has made it clear that although there is a single genetic cause, there are in fact numerous pathologic mechanisms that are unleashed in HD. While the multiplicity of disease mechanisms makes it unlikely that any single therapeutic approach will be successful, this complexity makes credible the idea that combination therapy could be successful. For example, while there have now been over 12 reports of slow disease progression in transgenic HD mice, recent studies indicate even more efficacy when two or more therapeutic agents are used in combination. "Rational therapy" therefore takes on a different connotation with respect to Huntington's disease. The first clinically suc- 
cessful therapies will likely target downstream mechanisms such as glutamate excitotoxicity or apoptosis. In conjunction with this approach, more upstream mechanisms will also be tested, such as mitochondrial compromise or transcriptional dysregulation. In the future, innovative therapies such as selective disease allele inactivation or neural transplantation are also like to play a valuable role in attacking HD. A combinatorial cocktail approach targeting each of these important mechanisms is likely to yield, at long last, an effective therapy for this dreaded disease.

\section{REFERENCES}

1. Botstein D, White RL, Skolnick M, Davis RW. Construction of a genetic linkage map in man using restriction fragment length polymorphisms. Am J Hum Genet 32:314-331, 1980.

2. Housman D, Gusella JF. Application of recombinant DNA techniques to neurogenetic disorders. Res Publ Assoc Res Nerv Ment Dis 60:167-172, 1983.

3. Gusella JF, Wexler NS, Conneally PM, Naylor SL, Anderson MA, Tanzi RE et al. A polymorphic DNA marker genetically linked to Huntington's disease. Nature 306:234-238, 1983.

4. Wexler NS, Rose EA, Housman DE. Molecular approaches to hereditary diseases of the nervous system: Huntington's disease as a paradigm. Annu Rev Neurosci 14:503-529, 1991.

5. Coyle JT, Schwarcz R. Lesion of striatal neurones with kainic acid provides a model for Huntington's chorea. Nature 263:244246, 1976.

6. McGeer EG, McGeer PL. Duplication of biochemical changes of Huntington's chorea by intrastriatal injections of glutamic acid and kainic acids. Nature 263:517-519, 1976.

7. Olney JW, de Gubareff T. Glutamate neurotoxicity and Huntington's chorea. Nature 271:557-559, 1978.

8. Beal MF, Kowall NW, Ellison DW, Mazurek MF, Swartz KJ, Martin JB. Replication of the neurochemical characteristics of Huntington's disease by quinolinic acid. Nature 321:168-171, 1986.

9. Choi DW. Glutamate neurotoxicity and diseases of the nervous system. Neuron 1:623-634, 1988.

10. Beal MF. Mechanisms of excitotoxicity in neurologic diseases. FASEB J 6:3338-3344, 1992.

11. Doble A. The role of excitotoxicity in neurodegenerative disease: implications for therapy. Pharmacol Ther 81:163-221, 1999.

12. Paulson HL, Fischbeck KH. Trinucleotide repeats in neurogenetic disorders. Annu Rev Neurosci 19:79-107, 1996.

13. Ross CA, Wood JD, Schilling G, Peters MF, Nucifora FC Jr, Cooper JK et al. Polyglutamine pathogenesis. Philos Trans R Soc Lond B Biol Sci 354:1005-1011, 1999.

14. Davies SW, Turmaine M, Cozens BA, DiFiglia M, Sharp AH, Ross CA et al. Formation of neuronal intranuclear inclusions underlies the neurological dysfunction in mice transgenic for the HD mutation. Cell 90:537-548, 1997.

15. DiFiglia M, Sapp E, Chase KO, Davies SW, Bates GP, Vonsattel JP, Aronin N. Aggregation of huntingtin in neuronal intranuclear inclusions and dystrophic neurites in brain. Science 277:19901993, 1997.

16. Price DL, Sisodia SS, Borchelt DR. Genetic neurodegenerative diseases: the human illness and transgenic models. Science 282: 1079-1083, 1998.

17. Taylor JP, Hardy J, Fischbeck KH. Toxic proteins in neurodegenerative disease. Science 296:1991-1995, 2002.

18. Shoulson I. Experimental therapeutics of neurodegenerative disorders: unmet needs. Science 282:1072-1074, 1998.

19. Huntington's disease, Ed 3 (Bates G, Harper P, Jones L, eds). New York: Oxford University, 2002.

20. Ranen NG, Peyser CE, Folstein SE. A physician's guide to the management of Huntington's disease: pharmacologic and nonpharmacologic interventions. New York: Huntington's Disease Society of America, 1993.
21. Vonsattel JP, Myers RH, Stevens TJ, Ferrante RJ, Bird ED, Richardson EP. Neuropathological classification of Huntington's disease. J Neuropathol Exp Neurol 44:559-577, 1985.

22. Dawbarn D, De Quidt ME, Emson PC. Survival of basal ganglia neuropeptide Y-somatostatin neurones in Huntington's disease. Brain Res 340:251-260, 1985.

23. Ferrante RJ, Kowall NW, Beal MF, Richardson EP Jr, Bird ED, Martin JB. Selective sparing of a class of striatal neurons in Huntington's disease. Science 230:561-564, 1985.

24. Ferrante RJ, Kowall NW, Beal MF, Martin JB, Bird ED, Richardson EP. Morphologic and histochemical characteristics of a spared subset of striatal neurons in Huntington's disease. $\mathrm{J} \mathrm{Neu-}$ ropathol Exp Neurol 46:12-27, 1987.

25. Kowall NW, Ferrante RJ, Martin JB. Patterns of cell loss in Huntington's disease. Trends Neurosci 10:24-29, 1987.

26. Cicchetti F, Parent A. Striatal interneurons in Huntington's disease: selective increase in the density of calretinin-immunoreactive medium-sized neurons. Mov Disord 11:619-626, 1996.

27. Cudkowicz M, Kowall NW. Degeneration of pyramidal projection neurons in Huntington's disease cortex. Ann Neurol 27:200204, 1990.

28. Hedreen JC, Peyser CE, Folstein SE, Ross CA. Neuronal loss in layers V and VI of cerebral cortex in Huntington's disease. $\mathrm{Neu}$ rosci Lett 133:257-261, 1991.

29. Augood SJ, Faull RLM, Emson PC. Dopamine D1 and D2 receptor gene expression in the striatum in Huntington's disease. Ann Neurol 42:215-221, 1997.

30. Weeks RA, Piccini P, Harding AE, Brooks DJ. Striatal D1 and D2 dopamine receptor loss in asymptomatic mutation carriers of Huntington's disease. Ann Neurol 40:49-54, 1996.

31. Antonini A, Leenders KL, Eidelberg D. [11C]raclopride-PET studies of the Huntington's disease rate of progression: relevance of the trinucleotide repeat length. Ann Neurol 43:253-255, 1998

32. Andrews TC, Weeks RA, Turjanski N, Gunn RN, Watkins LH, Sahakian B et al. Huntington's disease progression. PET and clinical observations. Brain 122:2353-2363, 1999.

33. Cha J-HJ, Frey AS, Alsdorf SA, Kerner JA, Kosinski CM, Mangiarini $\mathrm{L}$ et al. Altered neurotransmitter receptor expression in transgenic mouse models of Huntington's disease. Philos Trans $R$ Soc Lond B Biol Sci 354:981-989, 1999.

34. Cha J-HJ, Kosinski CM, Kerner JA, Alsdorf SA, Mangiarini L, Davies SW et al. Altered brain neurotransmitter receptors in transgenic mice expressing a portion of an abnormal human Huntington disease gene. Proc Natl Acad Sci USA 95:6480-6485, 1998.

35. Denovan-Wright EM, Robertson HA. Cannabinoid receptor messenger RNA levels decrease in a subset of neurons of the lateral striatum, cortex and hippocampus of transgenic Huntington's disease mice. Neuroscience 98:705-713, 2000.

36. The Huntington's Disease Collaborative Research Group. A novel gene containing a trinucleotide repeat that is unstable in Huntington's disease chromosomes. Cell 72:971-983, 1993.

37. Duyao MP, Ambrose CM, Myers RH, Novoletto A, Persichetti F, Frontali $\mathrm{M}$ et al. Trinucleotide repeat length instability and age of onset in Huntington's disease. Nat Genet 4:387-392, 1993.

38. Goldberg YP, Kremer B, Andrew SE, Theilmann J, Graham RK, Squitieri $\mathrm{F}$ et al. Molecular analysis of new mutations for Huntington's disease: Intermediate alleles and sex of origin effects. Nat Genet 5:174-179, 1993.

39. Koshy BT, Zoghbi HY. The CAG/polyglutamine tract diseases: gene products and molecular pathogenesis. Brain Pathol 7:927942, 1997.

40. Young AB. Huntington's disease and other trinucleotide repeat disorders. In: Scientific american molecular neurology (Martin JB, ed), pp 35-54. New York: Scientific American, 1998.

41. Cha J-HJ, Dure LS IV. Trinucleotide repeats in neurological diseases: an hypothesis concerning the pathogenesis of Huntington's disease, Kennedy's disease, and spinocerebellar ataxia type I. Life Sci 54:1459-1464, 1994.

42. Mangiarini L, Sathasivam K, Seller M, Cozens B, Harper A, Hetherington $\mathrm{C}$ et al. Exon 1 of the $H D$ gene with an expanded CAG repeat is sufficient to cause a progressive neurological phenotype in transgenic mice. Cell 87:493-506, 1996. 
43. Ordway JM, Tallaksen-Greene S, Gutekunst C-A, Bernstein EM, Cearley JA, Wiener HW et al. Ectopically expressed CAG repeats cause intranuclear inclusions and a progressive late onset neurological phenotype in the mouse. Cell 91:753-763, 1997.

44. Zeitlin S, Liu JP, Chapman DL, Papaioannou VE, Efstratiadis A. Increased apoptosis and early embryonic lethality in mice nullizygous for the Huntington's disease gene homologue. Nat Genet 11:155-163, 1995.

45. White JK, Auerbach W, Duyao MP, Vonsattel JP, Gusella JF, Joyner AL, MacDonald ME. Huntingtin is required for neurogenesis and is not impaired by the Huntington's disease CAG expansion. Nat Genet 17:404-410, 1997.

46. Leavitt BR, Guttman JA, Hodgson JG, Kimel GH, Singaraja R, Vogl AW, Hayden MR. Wild-type huntingtin reduces the cellular toxicity of mutant huntingtin in vivo. Am J Hum Genet 68:313324, 2001.

47. Metzler M, Helgason CD, Dragatsis I, Zhang T, Gan L, Pineault $\mathrm{N}$ et al. Huntingtin is required for normal hematopoiesis. Hum Mol Genet 9:387-394, 2000.

48. Rigamonti D, Bauer JH, De-Fraja C, Conti L, Sipione S, Sciorati $\mathrm{C}$ et al. Wild-type huntingtin protects from apoptosis upstream of caspase-3. J Neurosci 20:3705-3713, 2000.

49. Cattaneo E, Rigamonti D, Goffredo D, Zuccato C, Squitieri F, Sipione S. Loss of normal huntingtin function: new developments in Huntington's disease research. Trends Neurosci 24:182-188, 2001.

50. Rigamonti D, Sipione S, Goffredo D, Zuccato C, Fossale E, Cattaneo E. Huntingtin's neuroprotective activity occurs via inhibition of procaspase-9 processing. J Biol Chem 276:1454514548, 2001.

51. Zuccato C, Ciammola A, Rigamonti D, Leavitt BR, Goffredo D, Conti L et al. Loss of huntingtin-mediated BDNF gene transcription in Huntington's disease. Science 293:493-498, 2001.

52. Ona VO, Li M, Vonsattel JP, Andrews LJ, Khan SQ, Chung WM et al. Inhibition of caspase-1 slows disease progression in a mouse model of Huntington's disease. Nature 399:263-267, 1999.

53. Goldberg YP, Nicholson DW, Rasper DM, Kalchman MA, Koide HB, Graham RK et al. Cleavage of huntingtin by apopain, a proapoptotic cysteine protease, is modulated by the polyglutamine tract. Nat Genet 13:442-449, 1996.

54. Wellington CL, Ellerby LM, Hackam AS, Margolis RL, Trifiro MA, Singaraja R et al. Caspase cleavage of gene products associated with triplet expansion disorders generates truncated fragments containing the polyglutamine tract. J Biol Chem 273:91589167, 1998.

55. Goffredo D, Rigamonti D, Tartari M, De Micheli A, Verderio C, Matteoli $\mathrm{M}$ et al. Calcium-dependent cleavage of endogenous wild-type huntingtin in primary cortical neurons. $J$ Biol Chem 277:39594-39598, 2002.

56. Gafni J, Ellerby LM. Calpain activation in Huntington's disease. $J$ Neurosci 22:4842-4849, 2002.

57. Lunkes A, Lindenberg KS, Ben-Haiem L, Weber C, Devys D, Landwehrmeyer GB et al. Proteases acting on mutant huntingtin generate cleaved products that differentially build up cytoplasmic and nuclear inclusions. Mol Cell 10:259-269, 2002.

58. Hackam AS, Singaraja R, Wellington CL, Metzler M, McCutcheon K, Zhang TQ et al. The influence of huntingtin protein size on nuclear localization and cellular toxicity. J Cell Biol 141:10971105, 1998.

59. Peters MF, Nucifora FC Jr, Kushi J, Seaman HC, Cooper JK, Herring WJ, Dawson VL, Dawson TM, Ross CA. Nuclear targeting of mutant huntingtin increases toxicity. Mol Cell Neurosci 14:121-128, 1999.

60. Sieradzan KA, Mechan AO, Jones L, Wanker EE, Nukina N, Mann DM. Huntington's disease intranuclear inclusions contain truncated, ubiquitinated huntingtin protein. Exp Neurol 156:9299, 1999.

61. Kim M, Lee HS, LaForet G, McIntyre C, Martin EJ, Chang P et al. Mutant huntingtin expression in clonal striatal cells: dissociation of inclusion formation and neuronal survival by caspase inhibition. J Neurosci 19:964-973, 1999.

62. Wheeler VC, White JK, Gutenkunst C-A, Vrbanac V, Weaver M, Li X-J et al. Long glutamine tracts cause nuclear localization of a novel form of huntingtin in medium spiny striatal neurons in $H d h^{Q 92}$ and $H d h^{Q 111}$ knock-in mice. Hum Mol Genet 9:503-513, 2000.

63. Kegel KB, Meloni AR, Yi Y, Kim YJ, Doyle E, Cuiffo BG et al. Huntingtin is present in the nucleus, interacts with the transcriptional corepressor C-terminal binding protein, and represses transcription. J Biol Chem 277:7466-7476, 2002.

64. DiFiglia M. Excitotoxic injury of the neostriatum: a model for Huntington's disease. Trends Neurosci 13:286-289, 1990.

65. Bruyn RP, Stoof JC. The quinolinic acid hypothesis in Huntington's chorea. J Neurol Sci 95:29-38, 1990.

66. Beal MF, Ferrante RJ, Swartz KJ, Kowall NW. Chronic quinolinic acid lesions in rats closely resemble Huntington's disease. J Neurosci 11:1649-1659, 1991

67. London ED, Yamamura HI, Bird ED, Coyle JT. Decreased receptor-binding sites for kainic acid in brains of patients with Huntington's disease. Biol Psychiatry 16:155-162, 1981.

68. Young AB, Greenamyre JT, Hollingsworth Z, Albin R, D'Amato C, Shoulson I, Penney JB. NMDA receptor losses in putamen from patients with Huntington's disease. Science 241:981-983, 1988.

69. Dure LS, Young AB, Penney JB. Excitatory amino acid binding sites in the caudate nucleus and frontal cortex of Huntington's disease. Ann Neurol 30:785-793, 1991.

70. Levine MS, Klapstein GJ, Koppel A, Gruen E, Cepeda C, Vargas $\mathrm{ME}$ et al. Enhanced sensitivity to N-methyl-D-aspartate receptor activation in transgenic and knockin mouse models of Huntington's disease. J Neurosci Res 58:515-532, 1999.

71. Hodgson JG, Agopyan N, Gutekunst CA, Leavitt BR, LePiane F, Singaraja R et al. A YAC mouse model for Huntington's disease with full-length mutant huntingtin, cytoplasmic toxicity, and selective striatal neurodegeneration. Neuron 23:181-192, 1999.

72. Zeron MM, Chen N, Moshaver A, Lee AT, Wellington CL, Hayden MR, Raymond LA. Mutant huntingtin enhances excitotoxic cell death. Mol Cell Neurosci 17:41-53, 2001.

73. Zeron MM, Hansson O, Chen N, Wellington CL, Leavitt BR, Brundin P, Hayden MR, Raymond LA. Increased sensitivity to $\mathrm{N}$-methyl-D-aspartate receptor-mediated excitotoxicity in a mouse model of Huntington's disease. Neuron 33:849-860, 2002.

74. Behrens PF, Franz P, Woodman B, Lindenberg KS, Landwehrmeyer GB. Impaired glutamate transport and glutamate-glutamine cycling: downstream effects of the Huntington mutation. Brain 125:1908-1922, 2002.

75. Sun Y, Savanenin A, Reddy PH, Liu YF. Polyglutamine-expanded huntingtin promotes sensitization of N-Methyl-D-aspartate receptors via post-synaptic density 95. J Biol Chem 276 : 24713-24718, 2001.

76. Landwehrmeyer GB, Standaert DG, Testa CM, Penney JB Jr, Young AB. NMDA receptor subunit mRNA expression by projection neurons and interneurons in rat striatum. $J$ Neurosci 15 : 5297-5307, 1995.

77. Standaert DG, Friberg IK, Landwehrmeyer GB, Young AB, Penney JB, Jr. Expression of NMDA glutamate receptor subunit mRNAs in neurochemically identified projection and interneurons in the striatum of the rat. Brain Res Mol Brain Res 64:11-23, 1999.

78. Chen N, Luo T, Wellington C, Metzler M, McCutcheon K, Hayden MR, Raymond LA. Subtype-specific enhancement of NMDA receptor currents by mutant huntingtin. J Neurochem 72:1890_ 1898, 1999.

79. Friedlander RM. Apoptosis and caspases in neurodegenerative diseases. N Engl J Med 348:1365-1375, 2003.

80. Dragunow M, Faull RLM, Lawlor P, Beilharz EJ, Singleton K, Walker EB, Mee E. In situ evidence for DNA fragmentation in Huntington's disease striatum and Alzheimer's disease temporal lobes. Neuroreport 6:1053-1057, 1995.

81. Portera-Cailliau C, Hedreen JC, Price DL, Koliatsos VE. Evidence for apoptotic cell death in Huntington disease and excitotoxic animal models. J Neurosci 15:3775-3787, 1995.

82. Saudou F, Finkbeiner S, Devys D, Greenberg ME. Huntingtin acts in the nucleus to induce apoptosis but death does not corre- 
late with the formation of intranuclear inclusions. Cell 95:55-66, 1998.

83. Li SH, Lam S, Cheng AL, Li XJ. Intranuclear huntingtin increases the expression of caspase-1 and induces apoptosis. Hum Mol Genet 9:2859-2867, 2000.

84. Wellington C, Leavitt B, Hayden MR, Huntington disease: new insights on the role of huntingtin cleavage. J Neural Transm Suppl 58, 2000.

85. Wellington CL, Ellerby LM, Gutekunst CA, Rogers D, Warby S, Graham RK et al. Caspase cleavage of mutant huntingtin precedes neurodegeneration in Huntington's disease. J Neurosci 22: 7862-7872, 2002.

86. Sanchez I, Xu CJ, Juo P, Kakizaka A, Blenis J, Yuan J. Caspase-8 is required for cell death induced by expanded polyglutamine repeats. Neuron 22:623-633, 1999.

87. Kiechle T, Dedeoglu A, Kubilus J, Kowall NW, Beal MF, Friedlander RM et al. Cytochrome $\mathrm{C}$ and caspase-9 expression in Huntington's disease. Neuromolecular Med 1:183-195, 2002.

88. Schapira AHV. Mitochondrial function in Huntington's disease: clues for pathogenesis and prospects for treatment. Ann Neurol 41:141-142, 1997.

89. Cooper JM, Schapira AH. Mitochondrial dysfunction in neurodegeneration. J Bioenerg Biomembr 29:175-183, 1997.

90. Beal MF. Mitochondrial dysfunction in neurodegenerative diseases. Biochim Biophys Acta Bio Energetics 1366:211-223, 1998.

91. Fiskum G, Murphy AN, Beal MF. Mitochondria in neurodegeneration: acute ischemia and chronic neurodegenerative diseases. J Cereb Blood Flow Metab 19:351-369, 1999.

92. Antonini A, Leenders KL, Spiegel R, Meier D, Vontobel P, Weigell-Weber $M$ et al. Striatal glucose metabolism and dopamine D2 receptor binding in asymptomatic gene carriers and patients with Huntington's disease. Brain 119:2085-2095, 1996.

93. Jenkins BG, Koroshetz WJ, Beal MF, Rosen BR. Evidence for impairment of energy metabolisn in vivo in Huntington's disease using localized 1H NMR spectroscopy. Neurology 43:2689-2695, 1993.

94. Koroshetz WJ, Jenkins BG, Rosen BR, Beal MF. Energy metabolism defects in Huntington's disease and effects of coenzyme $\mathrm{Q}_{10}$. Ann Neurol 41:160-165, 1997.

95. Lodi R, Schapira AH, Manners D, Styles P, Wood NW, Taylor DJ, Warner TT. Abnormal in vivo skeletal muscle energy metabolism in Huntington's disease and dentatorubropallidoluysian atrophy. Ann Neurol 48:72-76, 2000.

96. Butterworth J, Yates CM, Reynolds GP. Distribution of phosphate activated glutaminase, succinic dehydrogenase, pyruvate dehydrogenase and gamma-glutamyl transpeptidase in post mortem brain from Huntington's disease and agonal cases. J Neurol Sci 67:161-171, 1985.

97. Gu M, Gash MT, Mann VM, Javoy-Agid F, Cooper JM, Schapira AH. Mitochondrial defect in Huntington's disease caudate nucleus. Ann Neurol 39:385-389, 1996.

98. Browne SE, Bowling AC, MacGarvey U, Baik MJ, Berger SC, Muqit MM et al. Oxidative damage and metabolic dysfunction in Huntington's disease: selective vulnerability of the basal ganglia. Ann Neurol 41:646-653, 1997.

99. Brouillet E, Hantraye P, Ferrante RJ, Dolan R, Leroy-Willig A, Kowall NW, Beal MF. Chronic mitochondrial energy impairment produces selective striatal degeneration and abnormal choreiform movements in primates. Proc Natl Acad Sci USA 92:7105-7109, 1995.

100. Palfi SP, Ferrante RJ, Brouillet E, Beal MF, Dolan R, Guyot MC, Peschanski M, Hantraye P. Chronic 3-nitropropionic acid treatment in baboons replicates the cognitive and motor deficits of Huntington's disease. J Neurosci 16:3019-3025, 1996.

101. Greene JG, Greenamyre JT. Characterization of the excitotoxic potential of the reversible succinate dehydrogenase inhibitor malonate. J Neurochem 64:430-436, 1995.

102. Henshaw R, Jenkins BG, Schulz JB, Ferrante RJ, Kowall NW, Rosen BR, Beal MF. Malonate produces striatal lesions by indirect NMDA receptor activation. Brain Res 647:161-166, 1994.

103. Calabresi P, Gubellini P, Picconi B, Centonze D, Pisani A, Bonsi $\mathrm{P}$, et al. Inhibition of mitochondrial complex II induces a longterm potentiation of NMDA-mediated synaptic excitation in the striatum requiring endogenous dopamine. $J$ Neurosci 21:51105120, 2001.

104. Albin RL, Greenamyre JT. Alternative excitotoxic hypotheses. Neurology 42:733-738, 1992.

105. Panov AV, Gutekunst CA, Leavitt BR, Hayden MR, Burke JR, Strittmatter WJ, Greenamyre JT. Early mitochondrial calcium defects in Huntington's disease are a direct effect of polyglutamines. Nat Neurosci 5:731-736, 2002.

106. Gines S, Seong IS, Fossale E, Ivanova E, Trettel F, Gusella JF et al. Specific progressive cAMP reduction implicates energy deficit in presymptomatic Huntington's disease knock-in mice. Hum Mol Genet 12:497-508, 2003.

107. Guidetti P, Charles V, Chen EY, Reddy PH, Kordower JH, Whetsell WO Jr et al. Early degenerative changes in transgenic mice expressing mutant huntingtin involve dendritic abnormalities but no impairment of mitochondrial energy production. Exp Neurol 169:340-350, 2001.

108. Cha J-HJ. Transcriptional dysregulation in Huntington's disease. Trends Neurosci 23:387-392, 2000.

109. Luthi-Carter R, Strand A, Peters NL, Solano SM, Hollingsworth $\mathrm{ZR}$, Menon AS et al. Decreased expression of striatal signaling genes in a mouse model of Huntington's disease. Hum Mol Genet 9:1259-1271, 2000.

110. Luthi-Carter R, Strand AD, Hanson SA, Kooperberg C, Schilling G, La Spada AR et al. Polyglutamine and transcription: gene expression changes chared by DRPLA and Huntington's disease mouse models reveal context-independent effects. Hum Mol Genet 11:1927-1937, 2002.

111. Kazantsev A, Preisinger E, Dranovsky A, Goldgaber D, Housman D. Insoluble detergent-resistant aggregates form between pathological and nonpathological lengths of polyglutamine in mammalian cells. Proc Natl Acad Sci (USA) 96:11404-11409, 1999.

112. Steffan JS, Kazantsev A, Spasic-Boskovic O, Greenwald M, Zhu Y-Z, Gohler H, Wanker E, Bates GP, Housman DE, Thompson LM. The Huntington's disease protein interacts with p53 and CBP and represses transcription. Proc Natl Acad Sci USA 97: 6763-6768, 2000.

113. Shimohata T, Nakajima T, Yamada M, Uchida C, Onodera O, Naruse $S$ et al. Expanded polyglutamine stretches interact with TAFII130, interfering with CREB-dependent transcription. Nat Genet 26:29-36, 2000.

114. McCampbell A, Taylor JP, Taye AA, Robitschek J, Li M, Walcott $\mathrm{J}$ et al. CREB-binding protein sequestration by expanded polyglutamine. Hum Mol Genet 9:2197-2202, 2000.

115. Dunah AW, Jeong H, Griffin A, Kim YM, Standaert DG, Hersch SM et al. Sp1 and TAFII130 transcriptional activity disrupted in early Huntington's disease. Science 296:2238-2243, 2002.

116. Li S-H, Cheng AL, Zhou H, Lam S, Rao M, Li H, Li X-J. Interaction of Huntington disease protein with transcriptional activator Sp1. Mol Cell Biol 22:1277-1287, 2002.

117. Orlando LR, Luthi-Carter R, Standaert DG, Coyle JT, Penney JB $\mathrm{Jr}$, Young AB. N-Acetylaspartylglutamate (NAAG) protects against rat striatal quinolinic acid lesions in vivo. Neurosci Lett 236:91-94, 1997.

118. Orlando LR, Standaert DG, Penney Jr. JB, Young AB. Metabotropic receptors in excitotoxicity: (S)-4-carboxy-3-hydroxyphenylglycine ((S)-4C3HPG) protects against rat striatal quinolinic acid lesions. Neurosci Lett 202:109-112, 1995.

119. Mary V, Wahl F, Stutzmann JM. Effect of riluzole on quinolinate-induced neuronal damage in rats: Comparison with blockers of glutamatergic neurotransmission. Neurosci Lett 201:92-96, 1995.

120. Rosas HD, Koroshetz WJ, Jenkins BG, Chen YI, Hayden DL, Beal MF, Cudkowicz ME. Riluzole therapy in Huntington's disease (HD). Mov Disord 14:326-330, 1999.

121. Seppi K, Mueller J, Bodner T, Brandauer E, Benke T, WeirichSchwaiger $\mathrm{H}$ et al. Riluzole in Huntington's disease (HD): an open-label study with one year follow-up. J Neurol 248:866869, 2001.

122. Schiefer J, Landwehrmeyer GB, Luesse HG, Sprunken A, Puls C, Milkereit A et al. Riluzole prolongs survival time and alters nuclear inclusion formation in a transgenic mouse model of Huntington's disease. Mov Disord 17:748-757, 2002. 
123. Mizuta I, Ohta M, Ohta K, Nishimura M, Mizuta E, Kuno S. Riluzole stimulates nerve growth factor, brain-derived neurotrophic factor and glial cell line-derived neurotrophic factor synthesis in cultured mouse astrocytes. Neurosci Lett 310:117-120, 2001.

124. Huntington Study Group. A randomized, placebo-controlled trial of coenzyme Q10 and remacemide in Huntington's disease. Neurology 57:397-404, 2001.

125. Ferrante RJ, Andreassen OA, Dedeoglu A, Ferrante KL, Jenkins BG et al. Therapeutic effects of coenzyme Q10 and remacemide in transgenic mouse models of Huntington's disease. $J$ Neurosci 22:1592-1599, 2002.

126. Schilling G, Coonfield ML, Ross CA, Borchelt DR. Coenzyme Q10 and remacemide hydrochloride ameliorate motor deficits in a Huntington's disease transgenic mouse model. Neurosci Lett 315:149-153, 2001.

127. Martel J, Chopin P, Colpaert F, Marien M. Neuroprotective effects of the alpha2-adrenoceptor antagonists, (+)-efaroxan and $(+/-)$-idazoxan, against quinolinic acid-induced lesions of the rat striatum. Exp Neurol 154:595-601, 1998.

128. Jakel RJ, Maragos WF. Neuronal cell death in Huntington's disease: a potential role for dopamine. Trends Neurosci 23:239245,2000

129. Reynolds GP, Dalton CF, Tillery CL, Mangiarini L, Davies SW, Bates GP. Brain neurotransmitter deficits in mice transgenic for the Huntington's disease mutation. $J$ Neurochem 72:1773-1776, 1999.

130. Yohrling GJ, Cha J-HJ. Neurochemistry of Huntington's disease. In: Huntington's disease, Ed 3 (Bates GP, Harper PS, Jones AL, eds), pp 276-308. London: Oxford Medical Publications, 2002.

131. Hickey MA, Reynolds GP, Morton AJ. The role of dopamine in motor symptoms in the R6/2 transgenic mouse model of Huntington's disease. J Neurochem 81:46-59, 2002.

132. Matthews RT, Yang L, Jenkins BG, Ferrante RJ, Rosen BR, Kaddurah-Daouk R, Beal MF. Neuroprotective effects of creatine and cyclocreatine in animal models of Huntington's disease. J Neurosci 18:156-163, 1998.

133. Ferrante RJ, Andreassen OA, Jenkins BG, Dedeoglu A, Kuemmerle S, Kubilus JK et al. Neuroprotective effects of creatine in a transgenic mouse model of Huntington's disease. J Neurosci 20:4389-4397, 2000.

134. Peyser CE, Folstein M, Chase GA, Starkstein S, Brandt J, Cockrell JR et al. Trial of d-alpha-tocopherol in Huntington's disease. Am J Psychiatry 152:1771-1775, 1995.

135. Ranen NG, Peyser CE, Coyle JT, Bylsma FW, Sherr M, Day L et al. A controlled trial of idebenone in Huntington's disease. Mov Disord 11:549-554, 1996.

136. Huntington Study Group. Safety and tolerability of the freeradical scavenger OPC-14117 in Huntington's disease. Neurology 50:1366-1373, 1998

137. Yrjanheikki J, Keinanen R, Pellikka M, Hokfelt T, Koistinaho J Tetracyclines inhibit microglial activation and are neuroprotective in global brain ischemia. Proc Natl Acad Sci USA 95:1576915774, 1998.

138. Yrjanheikki J, Tikka T, Keinanen R, Goldsteins G, Chan PH, Koistinaho J. A tetracycline derivative, minocycline, reduces inflammation and protects against focal cerebral ischemia with a wide therapeutic window. Proc Natl Acad Sci USA 96:1349613500, 1999.

139. Chen M, Ona VO, Li M, Ferrante RJ, Fink KB, Zhu S et al. Minocycline inhibits caspase- 1 and caspase- 3 expression and delays mortality in a transgenic mouse model of Huntington disease. Nat Med 6:797-801, 2000.

140. Dedeoglu A, Kubilus JK, Jeitner TM, Matson SA, Bogdanov M, Kowall NW et al. Therapeutic effects of cystamine in a murine model of Huntington's disease. J Neurosci 22:8942-8950, 2002.

141. Karpuj MV, Becher MW, Springer JE, Chabas D, Youssef S,
Pedotti R et al. Prolonged survival and decreased abnormal movements in transgenic model of Huntington disease, with administration of the transglutaminase inhibitor cystamine. Nat Med 8:143-149, 2002.

142. Lesort M, Lee M, Tucholski J, Johnson GV. Cystamine inhibits caspase activity. Implications for the treatment of polyglutamine disorders. J Biol Chem 278:3825-3830, 2003.

143. McCampbell A, Taye AA, Whitty L, Penney E, Steffan JS, Fischbeck KH. Histone deacetylase inhibitors reduce polyglutamine toxicity. Proc Natl Acad Sci USA 98:15179-15184, 2001.

144. Hughes RE, Lo RS, Davis C, Strand AD, Neal CL, Olson JM, Fields S. Altered transcription in yeast expressing expanded polyglutamine. Proc Natl Acad Sci USA 98:13201-13206, 2001.

145. Steffan JS, Bodai L, Pallos J, Poelman M, McCampbell A, Apostol BL et al. Histone deacetylase inhibitors arrest polyglutaminedependent neurodegeneration in Drosophila. Nature 413:739743, 2001.

146. Hockly E, Richon VM, Woodman B, Smith DL, Zhou X, Rosa E et al. Suberoylanilide hydroxamic acid, a histone deacetylase inhibitor, ameliorates motor deficits in a mouse model of Huntington's disease. Proc Natl Acad Sci USA 100:2041-2046, 2003.

147. Fink JS, Schumacher JM, Ellias SL, Palmer EP, Saint-Hilaire M, Shannon K et al. Porcine xenografts in Parkinson's disease and Huntington's disease patients: preliminary results. Cell Transplant 9:273-278, 2000.

148. Rosser AE, Barker RA, Harrower T, Watts C, Farrington M, Ho $\mathrm{AK}$ et al. Unilateral transplantation of human primary fetal tissue in four patients with Huntington's disease: NEST-UK safety report ISRCTN no 36485475. J Neurol Neurosurg Psychiatry 73: 678-685, 2002.

149. Hauser RA, Furtado S, Cimino CR, Delgado H, Eichler S, Schwartz S et al. Bilateral human fetal striatal transplantation in Huntington's disease. Neurology 58:687-695, 2002.

150. Freeman TB, Cicchetti F, Hauser RA, Deacon TW, Li XJ, Hersch SM et al. Transplanted fetal striatum in Huntington's disease: phenotypic development and lack of pathology. Proc Natl Acad Sci USA 97:13877-13882, 2000.

151. Greenamyre JT, Shoulson I. We need something better, and we need it now: fetal striatal transplantation in Huntington's disease? Neurology 58:675-676, 2002.

152. Hughes PE, Alexi T, Williams CE, Clark RG, Gluckman PD. Administration of recombinant human activin-A has powerful neurotrophic effects on select striatal phenotypes in the quinolinic acid lesion model of Huntington's disease. Neuroscience 92:197209, 1999.

153. Frim DM, Uhler TA, Short MP, Ezzedine ZD, Klagsbrun M, Breakefield XO, Isacson O. Effects of biologically delivered NGF, BDNF and bFGF on striatal excitotoxic lesions. Neuroreport 4:367-370, 1993.

154. Emerich DF, Lindner MD, Winn SR, Chen EY, Frydel BR, Kordower JH. Implants of encapsulated human CNTF-producing fibroblasts prevent behavioral deficits and striatal degeneration in a rodent model of Huntington's disease. J Neurosci 16:51685181,1996

155. Alberch J, Perez-Navarro E, Canals JM. Neuroprotection by neurotrophins and GDNF family members in the excitotoxic model of Huntington's disease. Brain Res Bull 57:817-822, 2002.

156. van Dellen A, Deacon R, York D, Blakemore C, Hannan AJ. Anterior cingulate cortical transplantation in transgenic Huntington's disease mice. Brain Res Bull 56:313-318, 2001.

157. Isacson $\mathrm{O}$. The production and use of cells as therapeutic agents in neurodegenerative diseases. Lancet Neurol 2:417-424, 2003.

158. Curtis MA, Penney EB, Pearson AG, van Roon-Mom WM, Butterworth NJ, Dragunow M, Connor B, Faull RL. Increased cell proliferation and neurogenesis in the adult human Huntington's disease brain. Proc Natl Acad Sci USA 100:9023-9027, 2003. 